\title{
IMPACT OF EMOTIONAL VALENCE AND DIFFERENT SOURCE PROBLEM CONDITIONS ON THE RESOLUTION OF ANALOGICAL TARGET PROBLEMS
}

\author{
Kinga IZSÓF JURÁSOVÁ ${ }^{1}$, Adam BIELA², Marián ŠPAJDEL ${ }^{3}$ \\ ${ }^{1}$ Department of Psychology, Faculty of Arts, University of Trnava \\ Hornopotočná 23, 91843 Trnava, Slovak Republic \\ E-mail: kinga.izsof.jurasova@gmail.com \\ ${ }^{2}$ Chair of Organization and Management Psychology, Faculty of Social Sciences \\ The John Paul II Catholic University of Lublin \\ Al. Racławickie 14, 20-950 Lublin, Poland \\ E-mail: bielaada@kul.lublin.pl \\ ${ }^{3}$ Laboratory of Cognitive Neuroscience, Institute of Normal and Pathological Physiology \\ Slovak Academy of Sciences \\ Sienkiewiczova 1,813 71 Bratislava, Slovak Republic \\ E-mail: mspajdel@gmail.com
}

\begin{abstract}
An experimental study was conducted to clarify the impact of the source problem (present/absent) and of the emotional valence (positive/negative) on the way analogical target problems are solved. Analogical problems were represented by two types of PC games. Film clips were used to elicit emotions, whereas emotional changes were monitored by SAM scale. It was found that the presence of source problem increased the speed of solving a target problem and led to analogical problem solving even though a non-analogical solution could also be conducted. Negative valence (feeling sad) facilitates analogical problem solving, whereas positive valence (feeling amused) alleviates non-analogical problem solving. Different emotional valence has no impact either on the length of the time needed for problem solving, or on the success.
\end{abstract}

Key words: analogy, problem solving, emotions, experiment

Solving analogical problems is a frequently occurring task, for example, when driving a car, shopping, cooking, etc. We intuitively know that those tasks we have faced in the past or experienced their solution in another way are solved faster and easier. It is also highly possible that the process of solving analogical problems may be influenced by emotional states, as is the case in other cognitive actions as attention, memory, decision making, etc. Negative and positive emotions in general have different effect on cognition as they influence the comprehension of the present situation.

Analogical inference is the process when one comes to a conclusion about a new situation through already acquired knowledge of very similar - analogical - situations. The first step in analogical inference is the identification of an analogy between a situation concerning an object, problem, domain, etc. in the past (source) and an unknown

DOI: $10.21909 / \mathrm{sp} .2014 .02 .653$ 
situation, object, problem, domain, etc. (target). An analogy can be stated only if the same relationship exists within the components of one object and within the components of another object. Similarity of components without similarity of their relations is not a valid criterion for an analogical connection (Biela, 1991, 1993). In his theory of structure-mapping Gentner (1983) highlighted structural similarity as the most important precondition of analogical relationship. It was demonstrated, however, that superficial similarity also plays a role in analogy detection-mainly in a retrieval of source domain (Blanchette, Dumbar, 2000).

Analogical inference is frequently used in a process of problem solving. Although it is a process of deriving logical conclusions, solving problems through it can be referred to only as a heuristic strategy because it does not guarantee the final, strict and effective solution (Bačová, 2011; Matlin, 1998). Analogical problem solving has the following main stages (Thagard, 2005; Dahl, Moreaue, 2002; Keane, Ledgeway, Duff, 1994):

1) Mental representation of the source problem

2) Retrieval of an already solved target problem from memory

3) Mapping and comparing the structure of the source and target problems

4) Transferring the solution from the source to the target problem based on structural similarity.

Gick and Holyoak (1980) proved in their broadly known experiment that the presence of the source problem facilitates the solution of the target problem also in conditions when they are structurally but not superficially similar.

Analogical problem solving is influenced, for example, by age (Singer-Freeman, Bauer,
2008; Viskontas et al., 2004), certain cognitive styles, gender, academic curricula (Antonietti, Gioletta, 1995), etc. We were mainly interested in whether different emotions could influence analogical problem solving. In general, emotional experience is described by two factors: valence (negative or positive) and arousal (calming or exciting) (Russell, Barrett, 1999). The relationship between emotions and cognition is intensively investigated in different areas of science and different perspectives, both throughout Slovakia (Jurásová, Špajdel, 2011, 2012; Kováč, 2010; Čavojová, 2010; Pilárik, Matuš́ková, 2010; Démuth, 2003), and abroad. It was proved that emotions influence the decision making process (Halama, 2011; Baumeister, DeWall, Zhang, 2007; Damasio, 1994), problem solving (Mikulincer, Sheffi, 2000; Blanchard-Fields, Jahnke, Camp, 1995), memory (Brierley et al., 2007; Ginet, Verkampt, 2007) and attention (Fredrickson, Branigan, 2005). While investigating the emotion-related surface similarities in analogical problem solving, Hesse, Kauer, Spies (1997) found that those target-relevant source problems are preferred that are emotionally congruent with target problems. Negative emotions in general lead to more thorough information processing and reduce the range of reasoning because they signalize an unpleasant or dangerous situation. One chooses the fastest and previously verified reaction, which can smoothly dissolve the situation eliciting negative emotion (Neidenthal, Krauth-Gruber, Rick, 2006; Stuchlíková, 2002). On the contrary, positive emotions widen the range of reasoning, reduce the thoroughness of information processing because they signalize a pleasant and safe situation, so one can try new ways of reaction. Routine is substituted by cre- 
ativity (Neidenthal, Krauth-Gruber, Rick, 2006; Stuchlíková, 2002).

The aim of our research was to verify whether the presence/absence of a source problem could modify the solution of an analogical target problem and whether the positive/negative emotional valence could influence the solution of an analogical target problem.

\section{METHOD}

\section{Participants}

A total of 110 (93 females, 17 males) undergraduates aged $18-25($ mean $=19.8)$ participated in the study. They were randomly divided into experimental and control sample. Participants volunteered for the research and gained no financial reward.

\section{Procedure}

A multivariational experimental design was used. The first independent variable was emotional valence, which could be rather positive or rather negative. Emotions were induced by film excerpts which were previously experimentally validated and proved to be effective in eliciting sadness (negative valence) and amusement (positive valence) (Izsóf Jurásová, Špajdel, 2013). We used a mute film clip from the movie "The
Bear" (1988) to elicit sadness, a film clip from the movie "Slnce, seno a pár facek" (Sun, hay and few slaps) (1989) to elicit amusement and a film clip from the movie "Hannah and Her Sisters" (1986) to induce neutral emotional state. Each participant watched each film clip (so they all experienced sadness, neutral emotional state and amusement during the research procedure). The sequence of the film clips was randomly generated by a PC program. The valence and arousal of induced emotions was measured by a non-verbal pictorial assessment technique "The Self-Assessment Manikin (SAM)". SAM was applied because it is a verified and broadly used technique in emotion evaluation (Backs, da Silva, Han, 2005; Jenning et al., 2000), can be filled out easily and quickly so it does not interfere with the induced emotional state. We did not measure the influence of emotional arousal on the solution of an analogical target problem because the applied film clips evoked resembling rate of emotional arousal.

The second independent variable was the type of a presented problem. Two types of PC games were used as source and target problems. The games were designed specifically for our research. In the first type of game ("Bridge"), The participant is supposed to build a bridge across the river by joining specifically designed supportive elements with bars (Figures 1 and 2).

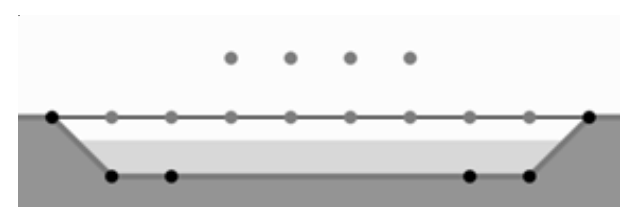

Figure 1. Model of gate no.1

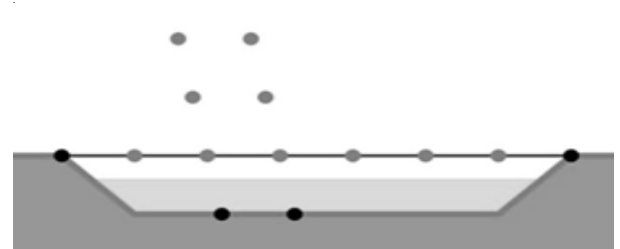

Figure 2. Model of gate no. 2 


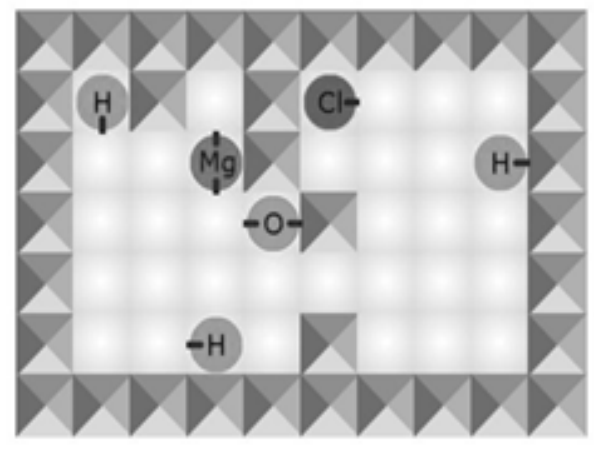

Figure 3. Model of labyrinth no.1

There was no time limit for the solution, one could test the stability of a bridge and rebuild it when fallen. Supportive elements could be connected in various ways, however, one should have taken into account the same physical laws that guarantee the analogy between the presented problems. In the second type of game ("Labyrinth"), participants were supposed to join some atoms - placed in different areas of the labyrinth to construct the molecule of water $(\mathrm{H}-\mathrm{O}-\mathrm{H})$ (Figures 3 and 4).

The motion of one atom can be stopped only by hitting a wall or another atom, that is why in all analogical problems one has to move more atoms than only one "H-“", "-O-“" and "-H". Participants were supposed to solve two analogical tasks from each game type. The tasks were superficially and also structurally similar.

The third independent variable was the source problem, which either was (experimental group) or was not presented (control group). All participants watched a short clip where PC games were introduced and the rules were explained. The experimental group saw a possible solution of a presented game

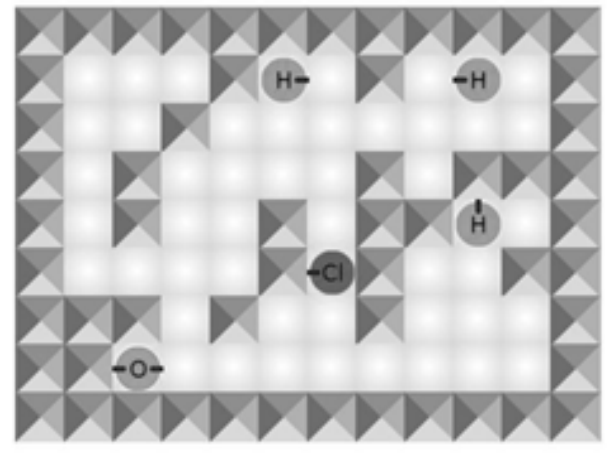

Figure 4. Model of labyrinth no.2

(source problem), while the control group was not familiarized with it (no source problem).

We measured the variance of dependent variables as a solution speed, strategy and successfulness of problem solving. The whole experiment was presented by a PC program, in a specific sequence (Table 1). The $\mathrm{PC}$ program recorded every action during the PC games solution and the speed of solution in order to enable retrospective quantitative evaluation of the solution strategy of participants.

\section{RESULTS}

Quantitative and qualitative methods were used in data evaluation. The strategy of target problem solving for each participant was evaluated by three appraisers and was declared analogic or non-analogic according to specific criteria. In the game "Bridge" for example it was monitored which supportive elements were joined, in which sequence and in what manner; whether the participant had a strategy in building or proceeded only at random. In the game "Laby- 
Table 1. Structure of the PC program for experimental and control group

\begin{tabular}{|l|l|}
\hline \multicolumn{1}{|c|}{ Experimental group } & \multicolumn{1}{c|}{ Control group } \\
\hline Clip for game "Bridge" - with solution & Clip for game "Bridge" - without solution \\
\hline Analogical problem - first "Bridge" game & Analogical problem - first "Bridge" game \\
\hline $\begin{array}{l}\text { Film excerpt - amusement or sadness } \\
\text { induction }\end{array}$ & $\begin{array}{l}\text { Film excerpt - amusement or sadness } \\
\text { induction }\end{array}$ \\
\hline \multicolumn{1}{|c|}{ SAM } & \multicolumn{1}{c|}{ SAM } \\
\hline Analogical problem - second "Bridge" game & Analogical problem - second "Bridge" game \\
\hline $\begin{array}{l}\text { Film excerpt - neutral emotional state } \\
\text { induction }\end{array}$ & $\begin{array}{l}\text { Film excerpt - neutral emotional state } \\
\text { induction }\end{array}$ \\
\hline \multicolumn{1}{|c|}{ SAM } & \multicolumn{1}{c|}{ SAM } \\
\hline Clip for game "Labyrinth" - with solution & $\begin{array}{l}\text { Clip for game "Labyrinth" - without } \\
\text { solution }\end{array}$ \\
\hline Analogical problem - first "Labyrinth" game & $\begin{array}{l}\text { Analogical problem - first "Labyrinth" } \\
\text { game }\end{array}$ \\
\hline $\begin{array}{l}\text { Film excerpt - amusement or sadness } \\
\text { induction }\end{array}$ & $\begin{array}{l}\text { Film excerpt - amusement or sadness } \\
\text { induction }\end{array}$ \\
\hline $\begin{array}{l}\text { Analogical problem - second "Labyrinth" } \\
\text { game }\end{array}$ & $\begin{array}{l}\text { Analogical problem - second "Labyrinth" } \\
\text { game }\end{array}$ \\
\hline
\end{tabular}

rinth", very similar criteria were applied but in this case the shift of atoms was assessed.

The impact of presence or absence of the source problem for the solution of the analogical target problem was measured for the games "Bridge" and "Labyrinth". It was found (Table 2) that the participants in the control group were slower in solving the target problem than the participants in the experimental group, but only in the game "Bridge" $(U=977 ; p=0.001 ; r=0.3)$. Differences between the groups in the speed of solution were not found in the game „Labyrinth" $(U=1444 ; p=0.68)$. Similarly we found differences between the groups in the strategy of solution (Table 3 ) in the game "Bridge" $\left(\chi^{2}(1)=45.35 ; \mathrm{p}<0.001 ;\right.$. Cramer's V $\left.=0.64\right)$ but not in the game "Labyrinth" $\left(\chi^{2}(1)=0.55\right.$; $p=0.45)$. When solving target problem the participants in the experimental group applied the same strategy as was presented in the source problem (clip for game "Bridge"), so they proceeded in analogical situation analogically. Finally, there were no differences between the experimental and the control group in the success of the solution of the game "Bridge" $\left(\chi^{2}(1)=0.96 ; p=0.32\right)$ and "Labyrinth“ $\left(\chi^{2}(1)=0.96 ; p=0.32\right)$. Interestingly, participants in the control group tested the stability of their bridge more frequently than the participants in the experimental group $(\mathrm{U}=717 ; \mathrm{p}<0.001 ; \mathrm{r}=0.47)$.

We also analyzed the impact of emotional valence on the solution of analogical target problem. Interestingly, no difference was found between the induced positive or nega- 
Table 2. Speed of solution of target problem in the game "Bridge" and "Labyrinth"

\begin{tabular}{|l|c|c|c|c|}
\hline \multirow{2}{*}{} & \multicolumn{2}{|c|}{ Bridge } & \multicolumn{2}{c|}{ Labyrinth } \\
\cline { 2 - 5 } & Median (s) & IQR & Median (s) & IQR \\
\hline Experimental group & 93 & 53 & 126 & 97 \\
\hline Control group & 121 & 72 & 131 & 112 \\
\hline
\end{tabular}

Table 3. Strategy of solution of target problem in the game "Bridge" and "Labyrinth"

\begin{tabular}{|l|c|c|c|c|}
\hline \multirow{2}{*}{} & \multicolumn{2}{|c|}{ Bridge } & \multicolumn{2}{c|}{ Labyrinth } \\
\cline { 2 - 5 } & Analogical & $\begin{array}{c}\text { Non- } \\
\text { analogical }\end{array}$ & Analogical & $\begin{array}{c}\text { Non- } \\
\text { analogical }\end{array}$ \\
\hline Experimental group & $89.3 \%$ & $10.7 \%$ & $67.9 \%$ & $32.1 \%$ \\
\hline Control group & $25.9 \%$ & $74.1 \%$ & $59.3 \%$ & $40.7 \%$ \\
\hline
\end{tabular}

tive emotional valence and the speed of solution in the game "Bridge" $(\mathrm{U}=1352.5 ; \mathrm{p}=$ $0.34)$ and "Labyrinth" $(U=1329 ; p=0.27)$. On the other hand, we found a relationship between the type of emotional valence and solution strategy in the game "Bridge" $\left(\chi^{2}\right.$ $(1)=4.40 ; p=0.03 ;$ Cramer's $V=0.2)$ as well as in the game "Labyrinth" $\left(\chi^{2}(1)=9.99 ; p<\right.$ 0.001 ; Cramer's $V=0.3)$. Negative emotional valence (feeling sad) was related to analogical strategy in solving analogical target problem, whereas positive emotional valence (feeling amused) was related to non-analogical strategy in solving analogical target problem. There was no relationship between the type of emotional valence and the successfulness of the "Labyrinth" game solution $\left(\chi^{2}\right.$ $(1)=0.29 ; p=0.58)$. The game "Bridge" was successfully solved by all participants after emotion elicitation.

\section{DISCUSSION}

Our first aim was to verify experimentally the effect of presenting a source problem on solving analogical target problem. It was found that if a source problem is presented, the target problem is solved more quickly, without hesitation and analogically. These findings are in accord with the results of Gick and Holyoak (1980). On the other hand, it is very interesting that no differences in successfulness between experimental and control group were detected when solving target problem. Moreover, the participants in the control group (no-source- problem condition) solved the target problem, especially the game "Bridge", more simply, effectively and in fewer steps than it was presented in the source problem. It can be assumed that the presence of a source problem stimulates analogical inference when solving an analogical target problem, accelerates a solution, evokes the feeling of competence but simultaneously reduces creative approach. However, it has to be highlighted that this tendency occurred only in the game "Bridge". When comparing clips with source problems for games "Bridge" and "Labyrinth" we concluded that the clip for the game "Bridge" 
was easier to understand and therefore induced analogical problem solving.

Our second aim was to determine whether different emotional valence could alter analogical problem solving. Our findings are in accord with the theoretical claims (Neidenthal, Krauth-Gruber, Rick, 2006; Stuchlíková, 2002) that negative valence stimulates well-known and verified reactions while positive valence stimulates experimental and creative tendencies. Participants experiencing negative emotional valence (feeling sad) solved analogical target problem analogically, in the same style as presented in the source problem. When experiencing positive emotional valence (feeling amused) they tried new methods, so they did not proceed analogically when solving analogical target problem. The synthesis of our findings can be represented in a scheme (Figure 5).
It can be stated that the prime source problem, which is sufficiently lucid and illustrative, facilitates analogical inference when solving analogical target problem. Similarly, negative emotional valence stimulates analogical problem solving. In a situation when one is acquainted with a source problem and concurrently experiences negative emotional valence, the tendency of analogical inference may increase, which results in applying well known steps in solving analogical problem. Positive emotional valence broadens the range of reasoning, motivates creative approach and experimental tendencies. We assume that the knowledge of a source problem when experiencing a positive emotional valence results primarily in analogical inference while solving analogical problems. That results in high speed of problem solving and a subjective feeling of competence.

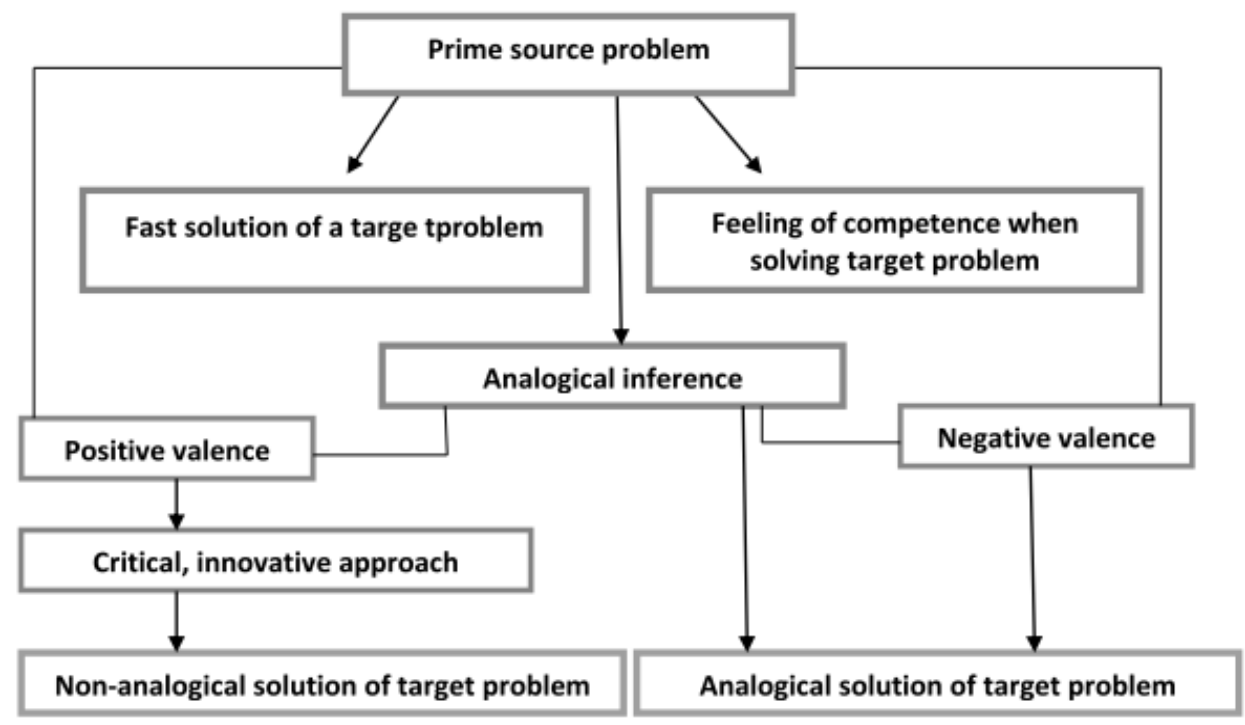

Figure 5. Scheme of the relationship between certain dependent and independent variables 
Yet, at the same time, the critical approach toward the analogical conclusion is maintained and it can be revised or improved through creativity and as a result not analogically solved.

When generalizing our findings we should reflect on the limits of this study. Our experiment utilized well-defined and quite simple PC games. This should be taken into account when considering the influence of the source problem on analogical target problem solving. This relationship is probably more complicated in real life conditions. Our participants were young university students, therefore, exploration of analogical inference in groups with different age and education is recommended. In follow-up studies it would be contributive to measure gender influence on analogical problem solving in various emotional valence conditions. Although men tend to apply analogical interference more frequently than women (Antonietti, Gioletta, 1995) we could not investigate this relationship because of the disproportion of men and women in our sample. We assume that various emotions (despite the same valence) could influence analogical problem solving differently, therefore, conducting the same experimental procedure with broader range of induced emotions would be desirable.

Received August 26, 2013

\section{REFERENCES}

ANTONietti, A., GiOlettA, M.A., 1995, Individual differences in analogical problem solving. Personality and Individual Differences, 18, 5, 611-619.

BACKS, R.W., DA SILVA, S.P., HAN, K., 2005, A comparison of younger and older adult's SelfAssessment Manikin ratings of affective pictures. Experimental Aging Research, 31, 4, 421-440.

BAČOVÁ, V., 2011, Klasická a ekologická racionalita $\mathrm{V}$ rozhodovaní: Spor o heuristiky. In: V.
Bačová (Ed.), Rozhodovanie a usudzovanie II. Oblasti a koncepcie (pp. 105-130). Bratislava: Ústav Experimentálnej Psychológie SAV.

BAUMEISTER, R.F., DEWALL, C.M., ZHANG, L., 2007, Do emotions improve or hinder the decision making process? In: K.D. Vohs, R.F. Baumeister, G. Loewenstein (Eds.), Do emotions help or hurt decision making?: A Hedgefoxian perspective (pp. 11-32). New York: Russel Sage Foundation.

BIELA, A., 1991, Analogy in science: From a psychological perspective. Frankfurt am Main: Peter Lang.

BIELA, A., 1993, Psychology of Analogical Inference. Stuttgart: Hirzel.

BLACHARD-FIELDS, F., JAHNKE, H.C., CAMP, C., 1995, Age differences in problem-solving style: The role of emotional salience. Psychology and Aging, 10, 2, 173-180.

BLANCHETTE, I., DUMBAR, K., 2000 , How analogies are generated: The roles of structural and superficial similarity. Memory \& Cognition, 29, 730-735.

BRIERLEY, B., MEDFORD, N., SHAW, P., DAVID, A.S., 2007, Emotional memory for words: Separating content and context. Cognition and Emotion, 21, 3, 495-521.

ČAVOJOVÁ, V., 2010, Rola emócií v rozhodovaní a ekonomickom správaní. In: V. Bačová (Ed.), Rozhodovanie a usudzovanie. Pohl'ady psychológie a ekonómie I. (pp. 133-161). Bratislava: Ústav Experimentálnej Psychológie SAV.

DAHL, D.W., MOREAU, P., 2002, The influence and value of analogical thinking during new product ideation. Journal of Marketing Research, 39, 47-60.

DAMASIO, A., 1994, Descartes' error: Emotion, reason, and the human brain. New York: Grosset/ Putnam.

DÉMUTH, A., 2003, Homo - anima cognoscens alebo o pozadi nášho poznávania. Bratislava: IRIS.

FREDRICKSON, B.L., BRANIGAN, C., 2005, Positive emotions broaden the scope of attention and thought-action repertoires. Cognition and Emotion, 19, 3, 313-332.

GENTNER, D., 1983, Structure-mapping: A theoretical framework for analogy. Cognitive Science, 7, 155-170.

GICK, M.L., HOLYOAK, K.J., 1980, Analogical Problem Solving. Cognitive Psychology, 12, 3, 306355. 
GINET, M., VERKAMPT, F., 2007, The cognitive interview: Is its benefit affected by the level of witness emotion? Memory, 15, 4, 450-464.

HALAMA, P., 2011, Emócie a emočná sebaregulácia $\mathrm{v}$ kontexte naturalistického rozhodovania. In: J. Gurňáková a kol., Úvod do naturalistického rozhodovania (pp. 91-107). Bratislava: Ústav Experimentálnej Psychológie SAV.

HESSE, F.W., KAUER, G., SPIES, K., 1997, Effects of emotion-related surface similarity in analogical problem solving. The American Journal of Psychology, 110, 3, 357-384

IZSÓF JURÁSOVÁ, K., ŠPAJDEL, M., 2013, Development and assessment of film excerpts used for emotion elicitation. Activitas Nervosa Superior Rediviva, 55, 3, 135-140.

JENNINGS, P.D., McGINNIS, D., LOVEJOY, S. STIRLING, J., 2000, Valence and arousal rating for Velten Mood Induction Statements. Motivation and Emotion, 24, 4, 285-297.

JURÁSOVÁ, K., ŠPAJDEL, M., 2011, The role of regret in rational decision making. Studia Psychologica, 53, 2, 169-174.

JURÁSOVÁ, K., ŠPAJDEL, M., 2012, Vzt'ah emócií a kognície z hl'adiska teórie kognitívneho zhodnotenia. Ostium, 8, 2, 1-7.

KEANE, M.T., LEDGEWAY, T., DUFF, S., 1994, Constraints on analogical mapping: A comparison of three models. Cognitive Science, 18, 3, 387-438.

KOVÁČ, D., 2010, Emócie v kogníciách: Zobudíme šípkovú ruženku? In: I. Ruisel, A. Prokopčáková (Eds.), Kognitívny portrét človeka (pp. 205-235). Bratislava: Ústav Experimentálnej Psychológie SAV.

MATLIN, M.W., 1998, Cognition. Orlando: Harcourt Brace College Publishers.
MIKULINCER, M., SHEFFI, E., 2000, Adult attachment style and cognitive reactions to positive affect: A test of mental categorization and creative problem solving. Motivation and Emotion, 24, 3, 149-174

NEIDENTHAL, P.M., KRANTH-GRUBER, S., RIC, F., 2006, Psychology of emotions: Interpersonal, experiental, and cognitive approach. New York: Psychology Press.

PILÁRIK, L', MATUŠÍKOVÁ, L., 2010, Emócie a rizikové rozhodovanie u vodičov. In: I. SarmánySchuller, L. Pilárik, E. Jurišová (Eds.), Rozhodovanie $v$ kontexte kognície, osobnosti a emócii II. Nitra: Fakulta sociálnych vied a zdravotníctva Univerzity Konštantína Filozofa v Nitre.

RUSSELL, J.A., BARRETT, L.F., 1999, Core affect, prototypical emotional episodes, and other things called emotion: Dissecting the elephant. Journal of Personality and Social Psychology, 76, 5, 805-819.

SINGER-FREEMAN, K.E., BAUER, P.J., 2008, The ABCs of analogical abilities: Evidence for formal analogical reasoning abilities in 24-month-olds. British Journal of Developmental Psychology, 26, 317-335.

STUCHLÍKOVÁ, I., 2002, Základy psychologie emocí. Praha: Portál.

THAGARD, P., 2005, Mind: Introduction to cognitive science. Cambridge: MIT Press.

VISKONTAS, I.V., MORRISON, R.G., HOLYOAK, K.J., HUMMEL, J.E., KNOWLTON, B.J., 2004, Relational integration, inhibition, and analogical reasoning in older adults. Psychology and Aging, 19, 4, 581-591.

\title{
VPLYVEMOCIONÁLNEJVALENICIEA RÔZNYCHPODMIENOK ZDROJOVÉHO PROBLÉMU NA SPÔSOB RIEŠENIA ANALOGICKÝCH CIELOVÝCH PROBLÉMOV
}

\author{
K. I z s ó f J u rá s ová, A. B i e 1 a, M. S̆ p a j d e 1
}

Súhrn: Ciel'om realizovaného experimentálneho výskumného plánu bolo objasnenie vplyvu zdrojového problému (prítomný/neprítomný) a emocionálnej valencie (pozitívna/negatívna) na spôsob riešenia analogických ciel'ových problémov. Analogické problémy boli modelované dvomi počítačovými hrami. Príslušné emócie boli evokované filmovými úryvkami, kým zmeny emócií boli zachytené pomocou škály SAM. Zistilo sa, že prítomnost' zdrojového problému urýchli riešenie ciel'ového problému a vedie $\mathrm{k}$ analogickému riešeniu napriek tomu, že i neanalogické riešenie by bolo efektívne. Negatívna emocionálna Valencia (smútok) vedie k analogickému riešeniu analogických problémov, kým pozitívna emocionálna Valencia (pobavenie sa) facilituje neanalogické riešenie analogických problémov. Zmeny v emocionálnej valencii sa neodrazia $\mathrm{v}$ rýchlosti a ani úspešnosti riešenia analogického ciel'ového problému. 